\title{
Zagadnienia konstrukcyjne umów publicznoprawnych
}

\section{Wprowadzenie}

Obserwujemy współcześnie wzrost znaczenia dwustronnych form działania administracji. Potrzeba uelastycznienia działań administracji w celu zwiększenia jej efektywności znajduje wyraz w korzystaniu z umów zawieranych w miejsce aktów administracyjnych. Umowy takie noszą różne nazwy ${ }^{1}$, bywa, że cechują się odmienną konstrukcja, a pomimo to zalicza się je do jednego zbioru tzw. „umów w administracji”2.

Należy podkreślić, że stosunkowo rzadko w doktrynie polskiej podejmowane są próby ujęcia umów publicznoprawnych w sposób kompleksowy, zwłaszcza w zakresie wskazania ich definicji i kategoryzacji. Należy natomiast zwrócić uwagę na cenne ujęcia tej problematyki w monografiach zbiorowych pod redakcją M. Stahl ${ }^{3}$, J. Zimmermanna ${ }^{4}$, J. Bocia ${ }^{5}$, J. Starościaka ${ }^{6}$ i Z. Cieślaka ${ }^{7}$.

${ }^{1} \mathrm{~W}$ doktrynie wskazuje się na: umowy administracyjne, tak J. Łętowski, Prawo administracyjne. Zagadnienia podstawowe, Warszawa 1990, s. 193; umowy publicznoprawne, tak D. Kijowski, W sprawie charakteru prawnego umów zawieranych przez organy administracji, "Państwo i Prawo" 1987, z. 6, s. 78.

${ }^{2}$ Szerzej na temat podziału prawnych form działania administracji zob. K. Ziemski, Indywidualny akt administracyjny jako forma prawna działania administracji, Poznań 2005.

${ }^{3}$ M. Stahl, Ugody, porozumienia administracyjne, umowy publicznoprawne, publiczne, administracyjne, umowy cywilne, w: Prawo administracyjne. Pojęcia, instytucje, zasady w teorii i orzecznictwie, pod red. M. Stahl, Warszawa 2016, s. 395.

${ }^{4}$ J. Zimmermann, Prawo administracyjne, Zakamycze 2006, s. 337-354.

${ }^{5}$ J. Boć, L. Dziewięcka-Bokun, Umowy w administracji, Wrocław 2008.

${ }^{6}$ J. Starościak, Prawne formy i metody działania administracji, w: System Prawa Administracyjnego, t. 3, pod red. T. Rabskiej, J. Łętowskiego, Wrocław 1978, s. 89, 97.

7 Z. Cieślak, Porozumienie administracyjne, Warszawa 1985; idem, Umowa administracyjna w państwie prawa, Zakamycze 2004. 
Poglądy doktryny na charakter, miejsce oraz konstrukcję umów publicznoprawnych nie są jednolite, co niewątpliwie wpływa na stanowienie tych umów w przepisach prawnych w sposób niekompletny, a czasem nawet niekonstytucyjny, a także na obniżenie ochrony praw jednostek, które zawierają takie umowy z organami administracji publicznej. Należy zauważyć już na wstępie, że charakterystyka umów $\mathrm{w}$ administracji nie jest zadaniem łatwym, nie jest to bowiem jednolita grupa form działania administracji.

Celem niniejszego artykułu jest próba odnalezienia wspólnych cech umów publicznoprawnych i odróżnienia ich od umów prywatnoprawnych zawieranych przez administrację, czemu posłuży zdefiniowanie umowy publicznoprawnej i wyodrębnienie jej elementów konstrukcyjnych.

Konieczne jest usystematyzowanie problematyki prawnych form działania administracji publicznej w zakresie kwalifikacji i wyróżnienia umowy publicznoprawnej oraz umowy prawa prywatnego, którą także posługują się organy administracji publicznej. W tym celu skorzystać można $z$ bogatego dorobku nauki francuskiej ${ }^{8}$ i niemieckiej ${ }^{9}$, ponieważ w tych porządkach prawnych wypracowano modelową konstrukcję umowy publicznoprawnej.

Trudności w kwalifikowaniu poszczególnych umów zawieranych przez administrację $\mathrm{w}$ polskim porządku prawnym powoduje liczne problemy z reżimem prawnym, jaki jest właściwy w przypadku ich niewykonania, nieterminowego wykonania oraz częściowo wadliwego wykonania. Rozważania w tym przedmiocie są podejmowane w doktrynie. I choć były akcentowane silnie podczas niejednej konferencji naukowej, wciąż brakuje jednoznacznego stanowiska w zakresie istoty i charakteru instytucji umowy publicznoprawnej.

Wypracowanie przez doktrynę wspólnych cech umów publicznoprawnych oraz ich definicji przyczyniłoby się niewątpliwie do realizacji ich celu, o którym już przed dziesięcioma laty wspominał J. Boć, wskazując, że umowa publicznoprawna daje zarówno obywatelowi, jak i innemu podmiotowi zewnętrznemu możliwości optymalnego

${ }^{8}$ M. Long, P. Weil, G. Braibant, P. Delvové, B. Genevois, Les grands arrêts de la jurisprudence administrative, Paris 2009, s. 67.

${ }^{9}$ B. Dolnicki, Umowa publicznoprawna w prawie niemieckim, „Państwo i Prawo" 2001, z. 3, s. 81; M. Ofiarska, Koncepcja umowy publicznoprawnej w niemieckiej nauce prawa administracyjnego, w: Jakość administracji publicznej, pod red. J. Łukasiewicza, Rzeszów 2004, s. 302-314. 
zjednoczenia interesu publicznego z jego interesem indywidualnym, a jeśli nie zjednoczenia, to przynajmniej jednoczesnego ulepszenia ochrony obydwu tych interesów ${ }^{10}$.

\section{Charakterystyka umów w administracji}

Już w okresie powojennym J.S. Langrod wskazywał, że w sferze form działania administracji jest miejsce na umowy w administracji. Autor ten nie nazywał ich umowami publicznoprawnymi, ale umowami prywatnymi wykorzystywanymi w działaniach administracji ${ }^{11}$. Następnie bardzo entuzjastycznie instrument, jakim są umowy publicznoprawne w działaniu administracji, przyjmował J. Filipek, który podkreślał przydatność umów i porozumień w polskim prawie administracyjnym ${ }^{12}$. W państwie socjalistycznym wykorzystywano i rozwijano porozumienie administracyjne, a na dalszym planie ze względów ustrojowych pozostawiano umowy administracji i jednostek ${ }^{13}$. Zmiany ustroju państwa polskiego po 1989 r. oraz przyjęcie nowej doktryny polityczno-prawnej odwołującej się do zasady demokratycznego państwa prawa dało miejsce dla rozwoju umów publicznoprawnych. Stanowienie nowych umów zawieranych przez administrację prowadzi do konieczności ustalenia ich charakteru i reżimu prawnego, który powinien być do nich stosowany. Ustalenie tego, czy dana umowa w administracji ma charakter cywilnoprawny czy administracyjnoprawny, jest ważne nie tylko ze względów dydaktycznych, ale przede wszystkim praktycznych. Od prywatnoprawnego bądź publicznoprawnego charakteru tych umów będzie zależeć m.in. ustalenie ich zasad konstrukcyjnych, a także to, jakie przepisy znajdą zastosowanie w kwestiach nieuregulowanych w ustawie kreującej daną umowę.

W zakresie charakteru tychże umów w doktrynie wyodrębnily się trzy nurty poglądów. Pierwszy z nich wskazuje, że są to instrumenty prawa cywilnego, z tym że jedną ze stron umowy jest organ administracji publicznej. Przedstawiciele tego stanowiska wskazują, że stosunki

${ }^{10} \mathrm{~J}$. Boć, O umowie w administracji, w: Umowy w administracji, pod red. J. Bocia, L. Dziewięckiej-Bokun, Wrocław 2008, s. 30.

${ }^{11}$ J.S. Langrod, Instytucje prawa administracyjnego. Zarys części ogólnej, Zakamycze 2003, s. 313-314.

12 J. Filipek, Stosunki administracyjnoprawne, Kraków 1968, s. 102.

${ }^{13}$ J. Starościak, Prawo administracyjne, Warszawa 1975, wyd. 3, s. 244. 
zobowiązaniowe mają charakter prywatnoprawny, a wyodrębnianie jakiegoś administracyjnego prawa zobowiązań mija się z celem. Byłoby to dopuszczalne tylko wtedy, gdyby udało się wykazać, że umowy te rządzą się zupełnie innymi, swoistymi prawami, tymczasem są to nieco zmodyfikowane umowy cywilnoprawne ${ }^{14}$. W ramach drugiego nurtu podkreślane jest, że wśród umów zawieranych przez administrację wyodrębnić można umowy publicznoprawne, czyli takie, które zostały uregulowane w ustawie w sposób zupełny, tzn. że przy ich stosowaniu nie ma podstaw do odwoływania się do przepisów Kodeksu cywilnego $^{15}$. Z kolei trzeci nurt poglądów koncentruje się na rozumieniu umowy jako instrumentu o mieszanym charakterze. Przedstawiciele nauki w ramach tego poglądu głosza, że umowy publicznoprawne są często regulowane częściowo przez prawo cywilne, a częściowo przez prawo administracyjne, mają zatem charakter mieszany, nadto podlegają kontroli sądów powszechnych ${ }^{16}$. J. Wyporska-Frankiewicz wskazuje, że umowy w administracji to umowy prawa cywilnego modyfikowane przez przepisy publicznoprawne, mające więc charakter mieszany, ale niekiedy modyfikacja jest tak znaczna, że chodzi już o nową jakość, nowy model umowy ${ }^{17}$.

Już przekrój przywołanych poglądów powoduje, że dochodzi do zróżnicowania tych form działania administracji w ustawach je stanowiących. Twórcy projektu III przepisów ogólnych prawa administracyjnego w $2010 \mathrm{r}$. podjęli próbę zdefiniowania umów publicznoprawnych ${ }^{18}$. W art. 41 projektu wskazano, że „organ administracji publicznej, właściwy do załatwienia sprawy z zakresu administracji publicznej, w drodze decyzji administracyjnej albo poprzez podjęcie innego aktu lub czynności władczej, uprawniony jest do zawarcia umowy z osobami, których interesów prawnych lub obowiązków sprawa dotyczy, o ile nie stoją temu na przeszkodzie przepisy szczególne (umowa administracyjna)".

${ }^{14}$ W.J. Jaworski, Nauka prawa administracyjnego. Zagadnienia ogólne, Warszawa 1924, s. 174; M. Zimmermann, Nauka administracji i polskie prawo administracyjne, Poznań 1949, s. 70 .

${ }^{15}$ Ustawa z dnia 23 IV 1964 r. Kodeks cywilny (tekst jedn. Dz.U. 2019, poz. 1145); P. Stec, Umowy w administracji. Studium cywilnoprawne, Warszawa 2013, s. 114; T. Beresiewicz, O kontraktach administracyjnych, Kraków 1901, s. 33.

${ }^{16}$ Z. Cieślik, Umowa administracyjna w państwie prawa, Kraków 2004, s. 83-84.

${ }^{17} \mathrm{~J}$. Wyporska-Frankiewicz, Publicznoprawne formy działania administracji o charakterze dwustronnym, Warszawa 2010, s. 248.

${ }^{18}$ Tekst projektu dostępny na: https://www.rpo.gov.pl/pliki/12059280660.pdf (dostęp: 6 VI 2019). 
Definicja wskazana w projekcie kładzie nacisk na przedmiot umowy, którym jest sprawa z zakresu administracji publicznej, a która może być załatwiona w drodze decyzji administracyjnej albo poprzez podjęcie innego aktu lub czynności władczej. Istotnymi cechami takiej umowy, nazwanej umową administracyjną, było także wskazanie, że kontrahentem organu może być każdy podmiot, również publiczny, o ile jego interesów prawnych lub obowiązków sprawa dotyczy. Podkreślić zatem należy, że umowa administracyjna mogłaby według tej definicji być zawarta wówczas, gdyby pomiędzy stronami nawiązany został stosunek administracyjny.

Przepisy te jednak nie zostały uchwalone; następnie w projekcie nowelizacji Kodeksu postępowania administracyjnego uchwalonym ustawą z dnia 7 kwietnia 2017 r. ${ }^{19}$ rozważano wprowadzenie do k.p.a. definicji umowy administracyjnej. Umowa administracyjna miała być alternatywnym rozstrzygnięciem sprawy (zamiast decyzji). Strona miałaby prawo wystąpienia do organu z wnioskiem o zawarcie umowy zamiast wydania decyzji i w sytuacji przyjęcia tego wniosku przez organ zawierana miała być umowa wyrażająca kompromisowy sposób załatwienia sprawy ${ }^{20}$. Ostateczny projekt ustawy nowelizującej nie zawierał już regulacji umowy administracyjnej. Należy wskazać, że na aprobatę zasługiwałaby próba uregulowania modelu i konstrukcji umów publicznoprawnych, a nie wyłącznie jej definicji w obliczu licznych sporów doktrynalnych. Ustawowe zdefiniowanie umowy administracyjnej nie położyłoby kresu sporom, gdyby taka definicja nie była przemyślana, kompleksowa i spójna systemowo. Projektodawcy nowelizacji Kodeksu postępowania administracyjnego nie zaproponowali dotąd regulacji kompleksowej, a zamieszczanie definicji umowy administracyjnej nie może być celem samym w sobie. $W$ takim przypadku ustawowa definicja może rodzić więcej problemów interpretacyjnych niż jej brak. Jedynie kompleksowa regulacja umów publicznoprawnych w połączeniu z jednolitym orzecznictwem mogłaby posłużyć administracji do poprawy jakości stosowania tej prawnej formy działania.

Przedstawiciele prawa administracyjnego podają różnice pomiędzy umowami publicznoprawnymi a umowami prywatnoprawnymi

${ }^{19}$ Ustawa z dnia 14 VI 1960 r. Kodeks postępowania administracyjnego (tekst jedn. Dz.U. 2018, poz. 2096), dalej „,k.p.a.”.

${ }^{20}$ Poszczególne wersje treści Rządowego projektu ustawy o zmianie ustawy - Kodeks postępowania administracyjnego oraz niektórych innych ustaw, druk sejmowy nr 1183/ VIII kadencja, http://www.sejm.gov.pl/SQL2.nsf/poskomprocall?OpenAgent\&8\&1183 (dostęp: 6 VI 2019). 
zawieranymi przez administrację. Według J. Bocia do elementów odróżniających umowy administracyjnoprawne od cywilnoprawnych należą: odmienne normy regulujące ich powstanie, treść oraz skutki stosunku prawnego, przedmiot umowy, szczególna pozycja strony publicznej, która może wpływać władczo na treść stosunku prawnego ${ }^{21}$. Natomiast J. Lemańska wskazuje, że rozróżnienie umów administracyjnoprawnych od cywilnoprawnych przeprowadzić można na podstawie analizy stopnia ich uregulowania przepisami administracyjnymi, znacznego ograniczenia zakresu swobody działania stron, szczególnego przedmiotu umowy w postaci zadania publicznego, silnego związania z administracją, a także wskazania odbiorcy usług będących przedmiotem umowy, świadczonych na rzecz odbiorcy powszechnego za stosunkowo niską opłatą ${ }^{22}$.

A. Kubiak wskazuje natomiast trzy charakterystyczne elementy konstrukcyjne umowy publicznoprawnej, tj.: a. określenie jako stron umowy dysponenta władzy publicznej oraz jego kontrahenta; b. przedmiot związany z publicznoprawnym zadaniem; c. zawieranie umów w procedurze administracyjnej i poddanie ich kontroli sądów administracyjnych $^{23}$.

Należy do tego dodać, że umowy publicznoprawne muszą być odmienne w swym charakterze od umów cywilnoprawnych, jeżeli mają zapewniać efektywne administrowanie i realizować interes publiczny. Nie służy temu autonomia woli stron i ich równość, właściwa dla prawa prywatnego. Umowy publicznoprawne, aby były efektywnym instrumentem, muszą charakteryzować się znamieniem władztwa po stronie organu.

Obecnie jednak ustawodawca, kreując umowy publicznoprawne, stanowi wyłącznie ich elementy, co powoduje znaczący chaos rozwiązań, zwłaszcza pod względem konstrukcji ${ }^{24}$.

Polska może czerpać wzorce z innych państw członkowskich Unii Europejskiej, w których model umów administracyjnych już dawno został wykształcony. W prawie francuskim znana jest konstrukcja umowy administracyjnej tzw. contrat administratif ${ }^{25}$, podobnie w nauce niemieckiej

\footnotetext{
${ }^{21}$ J. Boć, O umowie administracyjnoprawnej, s. 31.

${ }^{22} \mathrm{~J}$. Lemańska, Umowa administracyjna a umowa cywilnoprawna, w: Instytucje wspótczesnego prawa administracyjnego, pod red. I. Skrzydło-Niżnik, P. Dobosza, D. Dą̧ek, M. Smagi, Kraków 2001, s. 424-426.

${ }^{23}$ A. Kubiak, Perspektywy rozwoju form konsensualnych w polskim prawie administracyjnym, w: Umowy w administracji, s. 77.

${ }^{24}$ P. Stec, op. cit., s. 79.

${ }^{25}$ Szerzej zob. G. Vedel, Droit administratif, Paris 1973, s. 230.
} 
umowa taka została uregulowana i nosi nawę Verwaltungsvertrag ${ }^{26}$. W prawie niemieckim definicja umowy administracyjnej stanowi, że jest to forma działania prawa publicznego, jej przedmiotem są sprawy publiczne, a stroną musi być co najmniej jedna osoba prawna prawa publicznego. Umowa publicznoprawna występuje w kilku formach. Jest uregulowana w $\S \S 54-62$ ustawy o postępowaniu administracyjnym rządu federalnego $\left(\mathrm{VwVfG}_{\mathrm{w}}{ }^{27}\right.$ oraz $\mathrm{w}$ administracyjnych przepisach proceduralnych krajów związkowych. Ta forma działania administracji jest w Niemczech często stosowana, np. w obszarze publicznego prawa budowlanego, prawa ochrony środowiska i prawa dotacji unijnych. Podobnie w prawie polskim są obszary wykorzystywania umów publicznoprawnych, a przykładem mogą tu być regulacje umowy urbanistycznej, wywłaszczeniowej czy o dofinansowanie ze środków Unii Europejskiej w ramach programów operacyjnych.

W prawie francuskim umowa administracyjna to taka, którą zawiera podmiot administracji publicznej; może być tak zakwalifikowana ze względu na to, że taki status nadaje jej ustawa (np. umowa o partnerstwie publiczno-prywatnym oraz umowa koncesyjna) lub zostanie uznana za administracyjną w świetle orzecznictwa. W tym drugim przypadku umowa musi spełniać dwa warunki łącznie: formalny i materialny. Kryterium formalne sprowadza się do tego, że umowa może być uznana za administracyjną, jeśli chociażby po jednej ze stron występuje co najmniej jeden organ administracji publicznej. Jeśli zatem umowa zostaje zawarta między dwiema osobami prywatnymi, jest zasadniczo prywatnoprawna, nawet jeśli jedna z osób jest odpowiedzialna za realizację usługi publicznej. Warunek materialny dotyczy rodzaju sprawy będącej przedmiotem umowy. Sprawa musi mieć zatem charakter publicznoprawny ${ }^{28}$.

\section{Klasyfikacja umów w administracji}

Klasyfikacja umów w administracji nie jest jeszcze wykształcona w sposób ostateczny, najczęściej jednak autorzy dzielą te umowy na dwie zasadnicze grupy. Do pierwszej należą umowy cywilnoprawne

${ }^{26}$ Szerzej zob. H. Maurer, Allgemeines Verwaltungsrecht, München 1999, s. 347.

${ }^{27}$ Ustawa o postępowaniu administracyjnym w wersji ogłoszenia z 23 I 2003 r., BGBl., s. 102, ostatnio zmieniona ustawą z dnia 18 VII 2017 r., BGBl. I P. 2745, https://dejure. org/gesetze/BVwVfG (dostęp: 10 IV 2019).

${ }^{28}$ B. Asso, F. Monera, J. Hillairet, A. Bousquet, Contentieux administratif, Levallois Perret 2006, s. 21. 
wykorzystywane przez administrację, natomiast do drugiej zaliczyć można umowy publicznoprawne (zwane także umowami administracyjnymi). Podobnie A. Błaś wyróżnia dwa typy umów kwalifikowanych jako formy działania administracji: umowy cywilnoprawne i administracyjnoprawne, zwane także umowami publicznoprawnymi ${ }^{29}$. S. Biernat wyróżnia dwie kategorie umów w administracji:

a. umowy "zwykłe" - umowy cywilnoprawne wykorzystywane przez administrację do realizacji celów publicznych;

b. umowy "kwalifikowane" - umowy, których istotą jest przekazywanie podmiotom niepublicznym wykonywania zadań wraz z kompetencjami do stosowania administracyjnoprawnych form działania ${ }^{30}$.

Dalsze podziały odnoszą się już do rozróżnienia w grupie umów publicznoprawnych. D. Kijowski wskazuje w ramach umów publicznoprawnych trzy grupy: a. umowy międzynarodowe, b. porozumienia administracyjne, c. typowe umowy administracyjne ${ }^{31}$.

W ramach umów publicznoprawnych można wyróżnić także liczne podziały, chociażby według kryterium tego, w jakim akcie normatywnym zostały one uregulowane. Zgodnie z nim wyróżnić można: a. umowy, których treść jest regulowana w ustawie, np. umowy o partnerstwie publiczno-prywatnym, b. umowy regulowane w ustawie, których treść jest uzupełniona warunkami ogólnymi zawartymi w rozporządzeniu, np. umowy o refundację leków, c. umowy, których treść reguluje tylko akt wykonawczy, np. umowy w sprawie przyznania środków na podjęcie działalności gospodarczej, a także d. umowy o regulacji szczątkowej, np. umowy grantowe.

W doktrynie niemieckiej wskazuje się na dwa rodzaje umów publicznoprawnych: umowy koordynacyjnoprawne oraz subordynacyjnoprawne $^{32}$. Kryterium tego podziału stanowi rodzaj relacji między stronami, które przystępują do negocjacji prowadzących do zawarcia umowy. Umowy koordynacyjnoprawne zawierane są przez podmioty publiczne będące wobec siebie na równoważnych pozycjach. Przykładem może tu być porozumienie samorządowe w układzie horyzontalnym. Są to

${ }^{29}$ A. Błaś, Formy działania administracji w warunkach prywatyzacji zadań publicznych, w: Administracja i prawo administracyjne u progu trzeciego tysiąclecia, Łódź 2000, s. 335.

${ }^{30}$ S. Biernat, Prywatyzacja zadań publicznych. Problematyka prawna, Warszawa 1994, s. $121-124$.

${ }^{31}$ D. Kijowski, op. cit., s. 281.

${ }^{32}$ H.J. Wolff, O. Bachof, R. Stober, Verwaltungsrecht I, München 1994, s. 797; M. Imboden, Der verwaltungsrechtliche Vertrag, Basel 1958, s. 76. 
stosunki, których nie można regulować aktem administracyjnym. Natomiast umowy subordynacyjnoprawne zawierane są pomiędzy podmiotami, z których jeden pozostaje względem drugiego w stosunku podporządkowania, jeden z podmiotów mógłby aktem administracyjnym określić prawa i obowiązki drugiej strony stosunku administracyjnego. Umowy takie zawierane są przez organy administracji publicznej oraz przez podmioty prywatne. Typowym przykładem są umowy partnerstwa publiczno-prywatnego. Umowa tego rodzaju może zastępować akt administracyjny albo poprzedzać jego wydanie, lub też nie pozostawać w żadnym związku z aktem administracyjnym ${ }^{33}$.

Zwłaszcza w przypadku umów subordynacyjnoprawnych konieczne jest ustawowe ukształtowanie gwarancji dla podmiotów prywatnych przystępujących do takiej umowy wobec słabszej pozycji względem organu administracji publicznej.

Umowa publicznoprawna, zwłaszcza zawierana przez organ administracji z jednostka, powinna być uregulowana wyłącznie w ustawie. Reżim prawny takiej umowy powinien być zaostrzony względem reżimu obowiązującego w stosunku do umów zawieranych w ramach administracji.

Szczególna ochrona stron umowy powinna być związana przede wszystkim z nadzwyczajną zmianą stosunków prawnych i faktycznych, na których była zawarta umowa. W takim przypadku regulacja niemiecka opiera się na rozwiązaniach cywilistycznych. Głównym elementem gwarancji jest klauzula rebus sic stantibus, a zatem możliwość podważenia zasady związania stron umową. Nadto § $60 \mathrm{VwVfG}$ przewiduje możliwość dopasowania tekstu umowy do zmienionych okoliczności faktycznych. Zmiana umowy następuje mocą orzeczenia sądu, które jest wydawane, o ile ziszczą się ustawowe przesłanki istotności zmiany, która polega na pogorszeniu stosunków faktycznych, które gdyby były znane stronie umowy, to powstrzymałaby się ona od jej zawarcia, bądź na takiej zmianie przepisów prawa lub ich sądowej wykładni, które spowodowały, że przyrzeczone świadczenia w umowie stałyby się niedozwolone. $W$ prawie niemieckim jednak interes organu administracji publicznej jest chroniony szerzej, ponieważ organ może wypowiedzieć umowę, jeśli zagraża ona dobru wspólnemu poważnymi stratami. Takie rozwiązanie wyraźnie uprzywilejowuje organy administracji jako strony umowy administracyjnej. W prawie polskim brakuje regulacji ogólnej

${ }^{33}$ Z. Cieślik, op. cit., s. 44 i n. 
odnoszącej się do zmiany stosunków prawnych i faktycznych umowy publicznoprawnej, co niewątpliwie ma niekorzystne skutki dla stron takich umów, zwłaszcza podmiotów spoza sfery organów administracji publicznej.

Należy się także zastanowić nad ochroną prawną strony umowy administracyjnej pod względem kontroli takiej umowy przez sąd, mianowicie czy powinien wypowiadać się $\mathrm{w}$ tym przedmiocie sąd administracyjny czy powszechny. W prawie polskim najczęściej sprawy na kanwie umów publicznoprawnych zawieranych z organem administracyjnym rozpoznawane są przez sądy powszechne, a nie administracyjne, co należy ocenić pozytywnie ze względu na szersze kryteria kontroli sądowej oraz szerszy zakres rozstrzygnięć merytorycznych sądów powszechnych w stosunku do administracyjnych. Brak spójnej koncepcji umów publicznoprawnych powoduje, że to orzecznictwo kształtuje, jaki dana umowa ma charakter, a w konsekwencji, jaka jest jurysdykcja w sprawie ${ }^{34}$.

\section{Konstrukcja umów publicznoprawnych}

Należy wskazać, że umowa publicznoprawna jest obecnie rozumiana przez orzecznictwo sądów administracyjnych wąsko, jako prawna forma działania administracji publicznej będąca czynnością prawną, w sferze wewnętrznej zawierana pomiędzy podmiotami wykonującymi zadania publiczne w celu przeniesienia zadań i/lub kompetencji, a zatem i władztwa administracyjnego ${ }^{35}$. Umowa taka przybiera najczęściej postać porozumienia administracyjnego, za pomocą którego podmioty administracji publicznej podejmują współdziałanie przy realizowaniu zadań $^{36}$. Pozostałe umowy traktować można jako umowy w administracji. Jednakże optować należy za szerszym rozumieniem umowy publicznoprawnej, tak aby objęła ona także sferę zewnętrzną działalności administracji publicznej (tzw. umowy subordynacyjnoprawne).

${ }^{34}$ Postanowienie Naczelnego Sądu Administracyjnego (NSA) z 3 XII 2015 r., sygn. II GSK 3159/15, „Orzecznictwo NSA i WSA” 2016, z. 6, s. 91.

${ }^{35}$ Wyrok Wojewódzkiego Sądu Administracyjnego (WSA) w Poznaniu z 19 II 2013 r., sygn. II SA/Po 1049/12, LEX nr 1320799, dotyczący kwalifikacji jako umowy cywilnoprawnej umowy o zlecenie podmiotowi niepublicznemu prac projektowych $\mathrm{w}$ ramach procedury planistycznej.

${ }^{36}$ Wyrok WSA w Gdańsku z 17 V 2018 r., sygn. III SA/Gd 1033/17, LEX nr 2498754; wyrok NSA z 8 V 2018 r., sygn. II OSK 542/18, LEX nr 2527643. 
W szerszym rozumieniu umowę publicznoprawną ujmować można jako czynność prawną w sferze zewnętrznej bądź wewnętrznej, wielostronną, związaną ze stosunkiem administracyjnoprawnym pomiędzy stronami, której treścią są skonkretyzowane uprawnienia i obowiązki podmiotów prawa w ten stosunek zaangażowanych. Publicznoprawny przedmiot stanowi podstawowe kryterium wyodrębnienia umowy publicznoprawnej jako formy działalności organów administracji publicznej od umowy cywilnoprawnej. Kryterium rozróżnienia jest również cel realizacji takiej umowy, który w przypadku umów administracyjnoprawnych zmierza do zaspokojenia potrzeb publicznych wynikających z ustawowo nałożonych zadań do wykonania. Te kryteria identyfikują umowę publicznoprawną jako instrument prawny pozwalający na realizację służby publicznej. Dalej wskazać należy, że w przypadku umowy publicznoprawnej brak jest swobody kontraktowania, tj. kształtowania treści umów oraz wyboru podmiotu kontrahenta.

Podstawa prawna i treść umowy publicznoprawnej powinny być wskazane w przepisie rangi ustawowej. Tymczasem niekiedy treść umów $\mathrm{w}$ administracji regulowana jest $\mathrm{w}$ rozporządzeniach ${ }^{37}$. Taka praktyka może stanowić naruszenie konstytucyjnej zasady demokratycznego państwa prawnego, która wymaga, aby przepisy nakładające prawa i obowiązki na obywateli były regulowane tylko w drodze ustawowej albo $\mathrm{z}$ prawidłowo sformułowanym upoważnieniem ustawowym. Zgodnie $\mathrm{z}$ art. 7 Konstytucji $\mathrm{RP}^{38}$ organy mogą podejmować działanie tylko wówczas, gdy pozwala im na to określony przepis prawa, i tylko w granicach określonych przez ten przepis, który powinien mieć rangę ustawową. Całościowe uregulowanie praw i obowiązków stron w rozporządzeniu

${ }^{37}$ Przykładem wyznaczania ram prawnych dla umowy w rozporządzeniu jest regulacja z art. 12a ust. 3 Ustawy z dnia 27 VIII 1997 r. o rehabilitacji zawodowej i społecznej oraz zatrudnianiu osób niepełnosprawnych (tekst jedn. Dz.U. 2019, poz. 1172), który stanowi, że „Minister właściwy do spraw zabezpieczenia społecznego określi w drodze rozporządzenia:

1. warunki oraz tryb przyznawania i zwrotu środków, o których mowa w ust. 1,

2. formy zabezpieczenia zwrotu środków, o których mowa w ust. 1, w przypadku naruszenia warunków umowy dotyczącej ich przyznania,

3. wzór wniosku i niezbędne elementy umowy dotyczącej przyznania środków określonych w ust. 1". Rozporządzenie Ministra Pracy i Polityki Społecznej z dnia 17 X 2007 r. w sprawie przyznania osobie niepełnosprawnej środków na podjęcie działalności gospodarczej, rolniczej albo na wniesienie wkładu do spółdzielni socjalnej w $§ 6$ ust. 2 stanowi o elementach umowy publicznoprawnej.

${ }^{38}$ Konstytucja Rzeczypospolitej Polskiej z dnia 2 IV 1997 r. (Dz.U. Nr 78, poz. 483 ze zm.). 
narusza konstytucyjną hierarchię źródeł prawa. Rozporządzenia mają charakter aktów wykonawczych do ustaw i powinny jedynie doprecyzowywać sposób wykonania praw i obowiązków określonych w ustawie.

Należy podkreślić, że większość umów zawieranych przez administrację ma charakter mieszany, a nie wyłącznie administracyjnoprawny. Wąskie ujęcie umowy publicznoprawnej powoduje, że do nich zakwalifikować można jedynie porozumienia. Jednakże ze względu na rozbieżności orzecznictwa ${ }^{39} \mathrm{w}$ tym zakresie postulować należy, by ustawodawca wprowadził regulacje konstrukcyjne i gwarancyjne dla strony takiej umowy, której stosunek prawny zawiera elementy publicznoprawne, a organ administracji ma kompetencje o charakterze władczym, zakładającym jednostronne działanie wobec kontrahenta (umowy mieszane).

\section{Sposoby konstruowania poszczególnych umów w administracji}

Umowy w administracji zawierają często zbiór klauzul charakterystycznych dla umów cywilnoprawnych, które są wzbogacane o dodatkowe postanowienia ustawowe.

Można wyróżnić następujące metody konstruowania umów w administracji: a. klasyczną - zbliżoną do stosowanej przy tworzeniu umów cywilnoprawnych, b. „treści minimalnej”, c. „treści zupełnej” - zbliżoną do stosowanych w prawie pracy, d. „nakładek" - właściwą dla umów z udziałem administracji publicznej.

W sposób klasyczny sformułowana została umowa partnerstwa publiczno-prywatnego. Zgodnie z art. 7 ust. 1 ustawy o partnerstwie publicz-

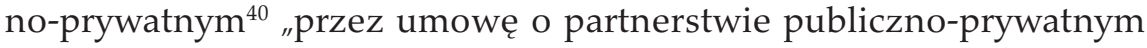

${ }^{39}$ Przykładowo wskazać można, że WSA w Olsztynie w wyroku z 13 III 2019 r., sygn. I SA/O1 119/19, LEX nr 2636558, stwierdza: „Polski system prawny nie przewiduje konstrukcji umowy publicznoprawnej. Stosunek umowny nawet między podmiotami prawa publicznego zawsze przybiera formę umowy cywilnoprawnej". Tak też WSA w Warszawie w wyroku z 7 IX 2017 r., sygn. III SA/Wa 3303/16, LEX nr 2352767, natomiast w odmienny sposób wypowiedział się NSA w wyroku z 7 III 2019 r., sygn. I GSK 1201/18, wskazując, że umowa o dofinansowanie zawiera także elementy publicznoprawne, należy bowiem odróżnić cywilnoprawne prawa i obowiązki stron składające się na węzeł obligacyjny umowy o dofinansowanie od obowiązków publicznoprawnych. Tak też wskazał NSA w wyroku z 9 VII 2015 r., sygn. II GSK 1390/14, LEX nr 1795823.

${ }^{40}$ Ustawa z dnia 19 XII 2008 r. o partnerstwie publiczno-prywatnym (tekst jedn. Dz.U. 2017, poz. 1834), dalej ,u.p.p.p.". 
partner prywatny zobowiązuje się do realizacji przedsięwzięcia za wynagrodzeniem oraz poniesienia w całości albo w części wydatków na jego realizację lub poniesienia ich przez osobę trzecią, a podmiot publiczny zobowiązuje się do współdziałania w osiągnięciu celu przedsięwzięcia, w szczególności poprzez wniesienie wkładu własnego". Przywołany przepis zawiera legalną definicję umowy o partnerstwie publiczno-prywatnym, określając jej essentialia negotii, jednocześnie wraz z art. 1 i 2 u.p.p.p. wspólnie określają pojęcie samego partnerstwa publiczno-prywatnego, wyznaczając jego zakres podmiotowy, przedmiotowy oraz podstawowe elementy stosunku prawnego. Umowa o partnerstwo publiczno-prywatne jest odrębnym typem umowy, którego normatywny wzorzec został uregulowany ustawą poprzez wskazanie jej istotnych cech. W związku z tym przyjąć należy, że jest to tzw. umowa nazwana $\mathrm{w}$ administracji.

Ustawodawca stosunkowo rzadko posługuje się definicjami klasycznymi w przypadku umów z udziałem administracji. Najczęściej stosuje metodę treści minimalnej bądź zupełnej. Rezygnacja z klasycznej definicji umowy i poprzestanie jedynie na enumeratywnym wyliczeniu klauzul, które strony powinny inkorporować do umowy, jest spowodowana tym, że są to umowy regulujące szeroki zakres zagadnień. Ustawodawca zamieszcza zatem listę postanowień koniecznych, ale nie zawsze wystarczających do stworzenia takiej umowy. Metoda treści minimalnej polega na tym, że wskazuje się w ustawie klauzule konieczne i wystarczające do zawarcia umowy, poprzez ich wyliczenie. Przykładem jest umowa o udzielenie świadczeń zdrowotnych. Artykuł 136 ustawy o świadczeniach opieki zdrowotnej finansowanych ze środków publicznych ${ }^{41}$ stanowi, że „umowa o udzielanie świadczeń opieki zdrowotnej określa w szczególności: 1) rodzaj i zakres udzielanych świadczeń opieki zdrowotnej; 2) warunki udzielania świadczeń opieki zdrowotnej".

Podobnie metodą treści minimalnej określona została umowa na realizację recept uregulowana $\mathrm{w}$ art. 41 ust. 2 ustawy o refundacji leków, środków spożywczych specjalnego przeznaczenia żywieniowego oraz wyrobów medycznych ${ }^{42}$, który stanowi, że „umowa na realizację recept określa w szczególności:

${ }^{41}$ Ustawa z dnia 27 VIII 2004 r. o świadczeniach opieki zdrowotnej finansowanych ze środków publicznych (tekst jedn. Dz.U. 2018, poz. 1510).

${ }^{42}$ Ustawa z dnia 12 V 2011 r. o refundacji leków, środków spożywczych specjalnego przeznaczenia żywieniowego oraz wyrobów medycznych (tekst jedn. Dz.U. 2019, poz. 784$)$. 
1) imię i nazwisko osoby będącej kierownikiem apteki;

2) wskazanie adresu prowadzenia apteki;

3) zobowiązanie do stosowania limitów, cen oraz odpłatności i dopłat świadczeniobiorcy w wysokości określonej w obwieszczeniu, o którym mowa w art. 37;

4) kary umowne;

5) warunki jej wypowiedzenia albo rozwiązania".

Natomiast w przypadku umów regulowanych metodą treści zupełnej ustawodawca wskazuje w przepisie elementy konieczne i wystarczające dla danej umowy, bez możliwości inkorporacji postanowień nieobjętych wyliczeniem. Jest to tzw. wariant "sztywny" umowy w administracji. Przykładem takiej umowy jest umowa o dotację celową uregulowana w art. 151 ust. 2 ustawy o finansach publicznych ${ }^{43}$, który stanowi, że „[u]mowa, o której mowa w ust. 1 [dotacji celowej], powinna określać:

1) szczegółowy opis zadania, w tym cel, na jaki dotacja została przyznana, i termin jego wykonania;

2) wysokość udzielonej dotacji i tryb płatności;

3) termin wykorzystania dotacji, nie dłuższy niż do dnia 31 grudnia danego roku budżetowego;

4) tryb kontroli wykonywania zadania;

5) termin i sposób rozliczenia udzielonej dotacji".

Spotkać się można również z konstrukcją umowy wykorzystującą tzw. nakładki. Polega to na uzupełnianiu kodeksowych modeli umów nazwanych o dodatkowe elementy, np. na wprowadzeniu modyfikacji co do sposobu wykonania umowy albo nałożeniu obowiązku zawarcia umowy na czas określony. W efekcie "zwykła” umowa cywilnoprawna nabiera cech wyspecjalizowanej umowy będącej umową publicznoprawną ze względu na pozycję stron ją zawierających.

Występują wreszcie i takie umowy z udziałem administracji, które nie zostały zdefiniowane, a ich treść opiera się na generalnym upoważnieniu do zawierania określonego rodzaju umów, jednak bez wskazania ich minimalnej treści. Do takich umów należy m.in. umowa o współpracy partnerskiej między jednostkami samorządu terytorialnego. Treść takich umów podlega w zasadzie swobodzie kontraktowej, jednakże ze względu na rodzaj stosunku łączącego strony, a także cel umowy powinna być ona zaliczana do umów o charakterze publicznoprawnym. Podobnie definicji legalnej nie ma umowa inicjatywy lokalnej. Elementy

${ }^{43}$ Ustawa z dnia 27 VIII 2009 r. o finansach publicznych (Dz.U. 2017, poz. 2077). 
tej umowy mogą zostać zdekodowane na podstawie całokształtu przepisów ustawy o działalności pożytku publicznego i o wolontariacie ${ }^{44}$. Należy wskazać, że przyczyną swobody kontraktowania w tego rodzaju umowach jest ich duża różnorodność. Trudno byłoby ustawodawcy wskazać ich uniwersalną treść, tak aby nadawała się ona do zastosowania w konkretnej sytuacji faktycznej.

\section{Treść umów w administracji}

Treść umowy publicznoprawnej składa się z: a. elementów przedmiotowo istotnych, nazywanych postanowieniami konstytutywnymi, odróżniającymi ją od innych czynności prawnych, b. dodatkowych elementów treści czynności prawnej, wprowadzanych wolą stron oraz c. elementów przedmiotowo nieistotnych, które wchodzą w jej skład na podstawie ustawy, ustalonych zwyczajów lub zasad współżycia społecznego.

Przechodząc do elementów przedmiotowo istotnych umowy, w przypadku powszechnych umów prawa cywilnego essentialia negotii są stosunkowo nieliczne i dają się łatwo wyinterpretować z definicji legalnych zawartych w Kodeksie cywilnym.

W przypadku umów w administracji jedynie te umowy, które są definiowane metodą klasyczna, zawierają elementy przedmiotowo istotne $\mathrm{w}$ ich definicji. Natomiast w umowach konstruowanych metodami "treści minimalnej" oraz "treści zupełnej” elementy przedmiotowo istotne muszą być odtwarzane na podstawie całokształtu uregulowań prawnych dotyczących danej umowy. Uregulowania te mogą być porozrzucane po wielu ustawach, a nawet w wytycznych, np. w przypadku umowy o dofinansowanie.

Pominięcie $\mathrm{w}$ umowie $\mathrm{w}$ administracji elementu przedmiotowo istotnego skutkuje odmiennie aniżeli w umowach cywilnoprawnych. W umowach regulowanych na podstawie prawa cywilnego niezawarcie takiego elementu powoduje jej nieważność. Do takiej umowy może zostać zastosowana konwersja polegająca na tym, że jeżeli umowa taka spełniła równocześnie wymogi innej czynności prawnej o zbliżonych, choć nie tak daleko idących skutkach prawnych, to w miejsce czynności nieważnej została dokonana czynność ważna, choć wywołująca skutki prawne mniejsze niż zamierzone. Skutki wadliwości umów

${ }^{44}$ Ustawa z dnia 24 IV 2003 r. o działalności pożytku publicznego i o wolontariacie (tekst jedn. Dz.U. 2019, poz. 688). 
regulowanych prawem publicznym mogą być bardzo różne, lecz nie zawsze wynikają z ustawy stanowiącej daną umowę. Nieważna i bez możliwości konwersji będzie umowa o partnerstwie publiczno-prywatnym, jeśli nie określa rodzaju realizowanego przedsięwzięcia, czyli elementu essentialia negotii. Natomiast umowa o udostępnienie informacji z państwowego zasobu kartograficznego, jeśli nie zawiera elementów essentialia negotii, może ulec konwersji w umowę licencyjną na korzystanie z bazy danych. Należy się zastanowić, czy cywilnoprawna paremia volenti non fit iniuria powinna być odczytywana wprost do umów publicznoprawnych. Wydaje się, że w przypadku umowy tego rodzaju ważne jest dokładne rozważenie, czy w konkretnym przypadku strona, która przystała na warunki umowy niezgodnej z prawem, np. narzuconej przez administrację, zasługuje na ochronę. Słusznie wskazuje doktryna niemiecka, że w takiej sytuacji, jeśli zasługuje na ochronę, to zaleca się odejście od absolutnego ujęcia zasady nieważności na rzecz utrzymania mocy obowiązującej umowy. Wyjątkowo można przyjąć, że nieważność dotyczy tylko części umowy ${ }^{45}$.

Accidentalia negotii, które nie wpływają na istotę umowy, nie stanowią jej obligatoryjnego elementu, ale mocą woli stron zostały podniesione do rangi istotnych, nie zawsze będą występowały w umowach publicznoprawnych. Niemożliwe będzie włączenie tych elementów do umów definiowanych metodą "treści zupełnej", ponieważ wskazana w ustawie treść wyczerpuje postanowienia tych umów. Włączenie elementów podmiotowo istotnych do umów $\mathrm{w}$ administracji jest możliwe w przypadku umów konstruowanych zarówno metodą klasyczną, jak i treści minimalnej.

Natomiast naturalia negotii są elementami treści czynności prawnej wchodzącymi w jej skład na podstawie ustawy, ustalonych zwyczajów lub zasad współżycia społecznego. Ustawy regulujące umowy w administracji odwołują się co do zasady do przepisów Kodeksu cywilnego, można zatem posiłkować się w ustalaniu treści tych umów zwyczajami i zasadami współżycia społecznego.

Ukazanie elementów konstrukcyjnych umów w administracji dowodzi, że nie są one tożsame z umowami cywilnoprawnymi. Mimo istnienia sporów w doktrynie co do charakteru prawnego takich umów, a więc czy stanowią one umowy publicznoprawne, czy też są szczególnym rodzajem umowy cywilnoprawnej, należy przyjąć, że nawet uznanie

${ }^{45} \S 59.3 \mathrm{VwVfG}$. 
ich mieszanego charakteru z przewagą cech aktu administracyjnego powoduje konieczność zapewnienia kompleksowych gwarancji dla słabszej strony takiego stosunku.

\section{Podsumowanie}

W doktrynie nie przyjęto w sposób jednoznaczny, jaki charakter mają umowy zawierane przez organ administracyjny i jego kontrahenta, nie dokonano także ostatecznego scharakteryzowania treści umów w administracji. Wciąż brakuje zgody co do konstrukcji umów publicznoprawnych oraz zasad nimi rządzących. Scharakteryzowanie umów zawieranych przez administrację publiczną nie jest zadaniem łatwym.

Instytucja umów w administracji dla wielu cywilistów jest instytucją niezrozumiałą. Również przedstawiciele nauki prawa i postępowania administracyjnego dalecy są od stworzenia katalogu takich umów, zastanawiają się bowiem nad sensem ich wyodrębnienia. To sądy administracyjne w przypadku sporów na ich tle każdorazowo oceniają, czy dana umowa może być zakwalifikowana do kategorii umów publicznoprawnych i należy do ich kognicji. Nawet zaliczenie danej umowy w administracji do umów publicznoprawnych nie powoduje, że takie umowy nie rodzą skutków cywilnoprawnych między stronami, a w konsekwencji także ich wzajemnej odpowiedzialności cywilnoprawnej. Umowy w administracji stanowią zatem twór hybrydowy z pogranicza prawa administracyjnego i cywilnego.

Celem stanowienia i zawierania takich umów jest polepszenie jakości administrowania, zwiększenie efektywności działań administracji i dostosowanie administracji do zmieniających się stosunków społeczno-ekonomicznych. Upowszechnienie umów administracyjnych stanowi też przejaw zasady decentralizacji państwa. Nadto idea poszerzenia stosowania umów publicznoprawnych jest zgodna z zasadą partycypacyjnej roli obywateli w osiąganiu efektów publicznych. Umowy zawierane $z$ administracją przez podmiot prywatny, pomimo uprzywilejowania pozycji organu, nadają większe uprawnienia jej kontrahentowi aniżeli w przypadku rozstrzygania sprawy aktem administracyjnym. Umowy tego rodzaju są sposobem na częściowo konsensualne uregulowanie przez organ administracji publicznej stosunków prawnych. Można więc oceniać je pozytywnie, z tym zastrzeżeniem, że spełnią one zamierzone funkcje wówczas, gdy będą wykorzystywane w takich sytuacjach, 
w których prawo jest wykonywane, a nie stanowione. Istotne dla prawidłowego posługiwania się instrumentem umowy przez administrację byłoby także wyodrębnienie jasnych, spójnych, właściwych prawu administracyjnemu wymogów związanych z jej zawieraniem, kontrolac legalności, możliwością zmiany i trwałością ${ }^{46}$. Tylko pod takimi warunkami można się zgodzić na dalszy rozwój tychże wielostronnych prawnych form działania administracji.

Niewątpliwie próba opracowania przepisów regulujących formy konsensualne $\mathrm{w}$ działalności administracji zasługiwałaby na rozważenie i aprobatę. Pełna regulacja umowy publicznoprawnej pozwoliłaby na dobrą realizację wyznaczonych jej funkcji, a także przyczyniła się do lepszej ochrony jednostki przed taką niewładczą formą działania administracji. Z pewnością jednak sama regulacja prawna umów tego rodzaju nie będzie stanowiła złotego środka, jeśli same organy administracji publicznej będą nadużywały władztwa w kształtowaniu sytuacji prawnej swoich kontrahentów.

\section{PUBLIC CONSTRUCTION CONTRACTS - SELECTED ISSUES}

\section{Su m mary}

The formulation of legal provisions by the administration does not have to take the form of administrative decisions. One of the legal forms of the administration is public-law contracts. This is one of the forms of administration which still requires a further scientific analysis.

Contracts are useful instruments, and therefore it may be worth looking at their different types and construction. They may be classified according to the parties to the legal relationship created. There are two types of contracts, i.e. between administrative bodies and between an administrative body and an entity. The doctrine refers to contracts of the latter type as administrative and legal agreements. Such agreements have developed in the Polish legal order after the systemic changes. Unfortunately, the legislator has not provided their legal definition, they are regulated in special laws, most often by indicating contractual provisions constituting essentialia negotii. The doctrine does not explicitly define the character of the contracts concluded by the administrative body and its contractor, nor has the final characteristics of the content of contracts in the administration as a whole been made. There is still a lack of consensus as to the construction of public law contracts and the rules governing them.

There is an urgent need to regulate the essence of administrative contracts, and in particular to indicate their construction and legal nature, in order to better

${ }^{46}$ Z. Cieślik, op. cit., s. 39. 
protect legal entities entering into them. The purpose of public-law contracts is to improve the quality of administration, and increase the efficiency of administrative activities. More administrative contracts also mean higher decentralisation of the state. Moreover, the idea of extending the use of public-law contracts is consistent with the principle of the participatory role of citizens in achieving public effects. The Polish legislator may draw on the regulations of other countries, for instance Germany, where public-law contracts have received legal definitions.

Keywords: public-law contracts - administrative agreements - legal forms of administration 